\title{
Booklet pada Materi Bakteri untuk Peserta Didik Kelas X SMA
}

\section{Olda Apriyeni ${ }^{1}$, Syamsurizal ${ }^{2}$, Heffi Alberida ${ }^{3}$, Yosi Laila Rahmi ${ }^{4}$}

1,23,4 Program Studi Pendidikan Biologi, Universitas Negeri Padang, Padang, Indonesia

\author{
A R T I C L E I N F O \\ Article history: \\ Received 15 April 2021 \\ Received in revised form \\ 30 April 2021 \\ Accepted 10 Mei 2021 \\ Available online 25 Juni \\ 2021 \\ Kata Kunci: \\ booklet materi bakteri, \\ sumber belajar \\ Keywords: \\ booklets on bacterial \\ material, learning resource
}

\begin{abstract}
A B S T R A K
Kegiatan belajar mengajar merupakan kegiatan yang paling mendasar dalam keseluruhan proses pendidikan. Keberhasilan pembelajaran itu sendiri tergantung pada penggunaan sumber belajar yang dipilih. Berdasarkan hasil angket observasi sumber belajar berupa buku teks, lembar kerja siswa (LKPD), slide PPT dan modul sudah tersedia dan digunakan di sekolah, namun masih diperlukan tambahan sumber belajar karena sumber belajar yang digunakan belum mampu menarik minat dan meningkatkan motivasi belajar siswa. Berdasarkan hal tersebut maka dikembangkan suatu produk berupa booklet materi untuk siswa kelas $X$ SMA yang valid dan praktis. Hasil rata-rata nilai validitas booklet sebesar $86,45 \%$ dengan kriteria sangat valid dengan uraian $84,25 \%$ pada aspek kelayakan isi, $88,33 \%$ pada aspek kebahasaan, $86,11 \%$ pada aspek penyajian, dan $87,50 \%$ pada aspek kegrafikan. Kesimpulan dari penelitian yang telah dilakukan adalah pengembangan booklet materi
\end{abstract} bakteri untuk siswa kelas X SMA memenuhi kategori sangat valid dan sangat layak digunakan sebagai sumber belajar.

A B S T R A K

Teaching and learning activities are the most basic activities in the entire educational process. The success of learning itself depends on the use of the selected learning resources. Based on the results of the observation questionnaire learning sources in the form of textbooks, student worksheets (LKPD), PPT slides and modules are available and used in schools, but additional learning resources are still needed because the learning resources used have not been able to attract interest and increase student learning motivation. Based on this, a product was developed in the form of a booklet on material for class X SMA students that was valid and practical. The average result of the booklet validity value is $86.45 \%$ with very valid criteria with a description of $84.25 \%$ in the content feasibility aspect, $88.33 \%$ in the linguistic aspect, $86.11 \%$ in the presentation aspect, and $87.50 \%$ in the the graphic aspect. The conclusion of the research that has been done is the development of booklets on bacterial material for class X SMA students fulfills the very valid category and is very suitable for use as a learning resource.

\section{Pendahuluan}

Media pembelajaran dalah salah satu komponen penting dalam proses pembelajaran. Adanya media pembelajaran dalam proses pembelajaran akan memberikan dampak positif. Agar media memberikan pengaruh yang positif tentunya media yang dibuat haruslah edukatif dan menarik (Kristiono \& Mutmainah, 2018; Nomleni \& Manu, 2018). Media yang menarik akan mampu mebuat suasana pembelajaran berbeda, hal ini akan berdampak terhadap peningkatan keaktifan siswa dalam proses pembelajaran (Dewi et al., 2020), serta meningkatkan motivasi siswa dalam proses pembelajaran (Panjaitan, 2017; Sukiyasa \& Sukoco, 2013). Media juga membawa pengaruh terhadap psikologis (batin, perasaan, sikap, dan karakter) siswa (Yusantika et al., 2018). Selain media yang dikembangkan harus menarik, media yang dirancang haruslah sesaui dengan materi yanga akan dibelajarakan, (Situmorang \& Andayani, 2019), karena media adalah alat perantara peyampakan materi dari pendidik ke peserta didik.

Copyright (C) Universitas Pendidikan Ganesha. All rights reserved 
oleh sebab itulah media yang dikembangkan harus memperhatikan karaeristik peserta didik. Tarutama saat ini, media pembelajaran sangat dibutuhkan dalam pembelajaran daring. Pembelajaran daring adalah salah satu pembelajaran yang memebrikan kesempatan kepada siswa untuk belajar lebih mandiri tanpa ada basa ruang dan waktu (Hwang et al., 2020; Kkese, 2020; Lage-Cala et al., 2020). Oleh karena itulah media sangat penting dalam proses pembelajaran daring.

Kenyataan dilapangan berbeda dengan apa yang diharapkan dimana dalam pembelajaran daring guru hanya menggunkan buku teks dan tugas-tugas. Hal ini tenunya akan sangat berdampak terhadap proses pembelajaran. Hasil analisis awal diperoleh bahawa pada materi bakteri ini siswa menggunakan sumber belajar berupa buku teks, lembar kerja peserta didik (LKPD), slide PPT dan modul. Berdasarkan analisis yang peneliti lakukan, sumber belajar yang digunakan tersebut kurang menarik karena kontenya hanya berupa ringkasan materi, belum terdapat kompetensi yang harus dicapai peserta didik, sumber belajar yang ada belum mampu membantu peserta didik mengaplikasikan konsep. Buku teks biasanya tebal dan berat, sehingga minat baca siswa menjadi rendah (Astuti et al., 2018; Lestari et al., 2019). Diantara siswa yang memiliki buku paket juga mengeluhkan akan beratnya membawa buku paket tersebut kesekolah, sehingga kebanyakan peserta didik tersebut meninggalkan buku paketnya dirumah. Saat siswa membuka buku teks, halaman yang mereka temukan adalah deretan huruf kecil, terkadang dengan gambar atau diagram (Fitriasih et al., 2019). Selain itu, terungkap bahwa sebanyak 73,09\% peserta didik menyatakan sulit memahami materi bakteri. Pemahaman konsep peserta didik pada materi bakteri secara keseluruhan cenderung kurang dan juga terdapat miskonsepsi pada subkonsep materi bakteri. Peserta didik kesulitan mempelajari materi bakteri karena kesulitan dalam memahami terminologi, memahami konsep, dan menuliskan nama ilmiah. Oleh sebab itu siswa membutuhkan sumber belajar lainnya seperti menggunakan bahasa yang mudah dimengerti, bewarna pada setiap halaman, materi yang disampaikan singkat, padat, dan jelas, bacaan disertai gambar, berukuran lebih kecil dan praktis, ada informasi tambahan mengenai materi dan ada penjelasan mengenai istilah yang sulit dipahami oleh siswa. Oleh karena itu, diperlukan sumber belajar yang dapat mendukung pembelajaran agar lebih efektif dan efesien. Salah satu sumber belajar adalah booklet.

Booklet merupakan media pendidikan berupa buku kecil yang berisi tulisan, gambar atau keduanya (Puspita et al., 2017; Rehusisma et al., 2017). Booklet tersebut dapat membantu siswa memahami materi yang dikenalkan oleh guru dan memberikan nuansa belajar yang menarik (Paramita et al., 2019). Media booklet yang dikemas menarik akan mampu meningkatkan hasil belajar (Intika, 2018) dapat meningkatkan pemahaman siswa (Yusuf et al., 2019). Booklet memiliki ukuran yang kecil, mudah dibawa dan dapat dipelajari (Hanzen et al., 2016; Wijayanti et al., 2016). Jadi dapat dikatakan bahwa media booklet berpengaruh positif karena bentuknya kecil, singkat dan menarik. Pernyataan ini diperkuat dengan hal penelitian yang menyatakan bahwa media booklet dengan huruf braille efektif dalam meningkatkan pengetahuan gizi pada anak tunanetra (Ulya et al., 2014), media booklet valid digunakan sebagai media informasi (Ajizatunnisa et al., 2018). Media booklet valid, pratis dan efesien diterapakan dalam proses pembelajaran (Ningrum \& Jayusman, 2017). Jadi dapat dikatakan bahwa media booklet mampu membuat suanasan pembelajaran lebih menarik. Media ini tidak hanya dikembangkan sebagai media pembelajaran namuan juga dikembangkan sebagai sumber informasi untuk hutan mangrove.

Jabaran tersebut menjadi alasan penelitian yang bertujuan untuk menganalisis Validitas Booklet pada Materi Bakteri untuk Peserta Didik Kelas. Media yang dikembangkan ini bebeda dnegan media yang sudah ada seblumnya karena materi yang akan dibuatkan materinya adalah materi bekteri. Namun penelitian ini hanya dilakukan pada tahap validias media saja dan pada tahapa penyebarannya tidak dilakukan karena masih pandemic.

\section{Metode}

Penelitian ini merupakan penelitian pengembangan yang menggunakan 3 tahapan model 4-D yang terdiri dari define, design, develop dan disseminate, namuan tahap disseminate tidak bisa dilakukan mengingat kondisi saat ini. Pada tahap define (pendefinisian) dilakukan untuk menetapkan dan mendefenisikan syarat-syarat pembelajaran. pada tahap ini dilakukan analisis kebutuhan, analisis pembelajaran, analisis kurikuluam dan analisis konsep. Analisis tersebut dilakukan untuk mengetahui focus pengembangan media booklet. Tahap design (perancangan) yang dilaksanakan untuk menghasilkan booklet biologi pada materi bakteri. Pada tahap desain ini disesauikan dengan analisis yang sudah dilakukan sebalumnya. Pada tahap ini peneliti mendesain booklet sesaui dengan materi dan karakteristik siswa. Tahap develop (pengembangan) dilakukan validasi oleh 2 orang dosen Biologi FMIPA UNP dan 1 orang guru mata pelajaran biologi, serta praktikalitas dilakukan oleh guru mata pelajran biologi dan peserta didik kelas X SMA Adabiah 2 Padang. Metode pengumpulan data yang digunakan adalah angket yang nantinya akan diisi oleh validator. Indicator yang digunakan untuk menilai booklet yang dikembangkan berkaitan dengan aspek isi, dan media. Validator menilai validitas booklet dengan cara 
mengisi instrumen penelitian berupa angket. Angket yang diisi validator memuat penilaian dari aspek kelayakan isi, kebahasaan, penyajian, dan kegrafikan. Nilai validitas booklet dikelompokkan berdasarkan kriteria penilaian sesuai dengan kriteria yang dimodifikasi dari Arikunto (2010:35) sebagai berikut. 1) $81 \%-100 \%=$ Sangat Valid; 2) $61 \%-80 \%=$ Valid; 3) $41 \%-60 \%=$ Tidak Valid; dan $\geq 21 \%-40 \%=$ Sangat Tidak Valid.

\section{Hasil dan Pembahasan}

Hasil

Hasil anlisis rata-rata nilai angket validitas booklet pada materi bakteri untuk peserta didik kelas X SMA sebesar $86,54 \%$. Hasil tersebut didapatkan dari penilaian tingkat validitas booklet pada aspek kelayakan isi, kebahasaan, penyajian dan kegrafikan berdasarkan penilaian dari validator. Hasil validitas booklet dapat dilihat pada Tabel 1.

Tabel 1. Hasil Validitas booklet pada Materi Bakteri untuk Peserta Didik Kelas X

\begin{tabular}{clcl}
\hline No & Aspek Penilaian & Nilai Validitas (\%) & Kriteria \\
\hline 1 & Kelayakan Isi & 84,25 & Sangat Valid \\
2 & Kebahasaan & 88,33 & Sangat Valid \\
3 & Penyajian & 86,11 & Sangat Valid \\
4 & Kegrafikan & 87,50 & Sangat Valid \\
\hline Total & $\mathbf{3 4 6 , 1 9}$ & Sangat valid \\
\hline Rata-rata & $\mathbf{8 6 , 5 4}$ & \\
\hline
\end{tabular}

Pada proses validitas booklet peneliti mendapatkan banyak saran dari validator untuk perbaikan booklet agar lebih baik lagi. Saran yang diberikan oleh validator terdapat pada Tabel 2.

Tabel 2. Saran dari Validator untuk Pengembangan Booklet pada Materi Bakteri untuk Peserta Didik Kelas X SMA

\begin{tabular}{|c|c|c|}
\hline No & Nama & Saran \\
\hline 1. & Validitor 1 & $\begin{array}{ll}\text { a. } & \text { Gambar diusahakan lebih komunikatif dan sesuaikan dengan materi } \\
\text { b. Materi lebih diperdalam dengan meminimalisir ruang gambar } \\
\text { c. Pada daftar gambar dan daftar tabel ditambahkan tulisan halaman } \\
\text { d. Gambar pada bagian info bio diganti dengan gambar yang lebih sesuai } \\
\text { e. Sesuaikan gambar dengan materi yang dibahas } \\
\text { f. }\end{array}$ \\
\hline 2. & Validitor 2 & $\begin{array}{l}\text { a. Samakan ukuran spasi pada bagian pendahuluan, daftar isi, dan } \\
\text { bagian isi } \\
\text { b. Pada bagian inti booklet tulisannya di ganti dengan rata kiri } \\
\text { c. Logo cukup logo kemendikbud dan unp saja, yang posisinya di kiri } \\
\text { bawah pada cover } \\
\text { d. Tulisan pada halaman cover spasinya } 1 \text { saja } \\
\text { e. Pada bagian judul pendahuluan, daftar isi, daftar gambar, dll tidak } \\
\text { perlu di beri warna outlinenya } \\
\text { f. Pada bagian skema pembelajaran ukuran tulisannya terlalu kecil } \\
\text { g. Sesuaiakan gambar dengan judul gambar } \\
\text { h. Sesuaikan aturan penulisan daftar pustaka } \\
\text { i. Ganti foto pada halaman biodata penulis }\end{array}$ \\
\hline 3. & Validitor 3 & $\begin{array}{l}\text { a. Perbaiki kesalahan penulisan } \\
\text { b. Carilah defenisi materi yang baik dan mudah dipahami peserta didik } \\
\text { c. Tambahkan gambar pada bagian inti booklet }\end{array}$ \\
\hline
\end{tabular}

\section{Pembahasan}

Hasil penelitian menyatakan bahwa media booklet yang dikembangkan layak digunakan, dilihat dari aspek isi, kebahasaan, penyajian dan aspek kegrafikan. Berdasarkan hasil validitas booklet pada aspek kelayakan isi booklet dinyatakan sangat valid. Hal ini menunjukkan booklet pada materi bakteri yang telah dikembangkan sesuai dengan kurikulum 2013. Booklet yang telah dikembangkan isinya juga telah disesuaikan dengan tingkat perkembangan berfikir peserta didik. Isi booklet juga telah sesuai 
dengan kebutuhan peserta didik yang mengiginkan sumber belajar yang menggunakan bahasa yang mudah dipahami, bewarna pada setiap halaman, materi yang disampaikan singkat, padat, dan jelas, berukuran lebih kecil dan praktis, ada informasi tambahan mengenai materi, terdapat penjelasan untuk istilah-istilah yang sulit dipahami, dan bacaan disertai gambar. Media yang dirancang haruslah sesaui dengan materi yanga akan dibelajarakan, (Situmorang \& Andayani, 2019). Media yang sesaui dengan materi akan membuat siswa paham lebih dalam tentang materi yang disampaikan. Booklet tersebut dapat membantu siswa memahami materi yang dikenalkan oleh guru dan memberikan nuansa belajar yang menarik (Paramita et al., 2019). Dengan adanya gambar dan ilustrasi pada media yang dikembangkan akan lebih bisa menggambrakan materi yang bersifat abstrak serta membuat media lebih menarik (Pralisaputri et al., 2016). Media booklet yang dikemas menarik akan mampu meningkatkan hasil belajar (Intika, 2018) dapat meningkatkan pemahaman siswa (Yusuf et al., 2019).

Berdasarkan hasil validitas booklet pada aspek kebahasan booklet termasuk dalam kriteria sangat valid. Hal tersebut menunjukkan bahwa kalimat yang digunakan pada booklet sesuai dengan kaidah ejaan Bahasa Indonesia yang baik dan benar. Bahasa yang digunakan pada booklet juga komunikatif dan interaktif yang disesuaikan dengan tingkat perkembangan usia peserta didik, sehingga informasi yang terdapat pada booklet nantinya dapat dengan mudah dipahami. Isi booklet juga dibuat dengan jenis tulisan yang jelas dan ukuran huruf yang mudah dibaca, sehingga peserta didik tidak kesulitan untuk membaca kalimat yang ada pada booklet. Ukuran dan jenis huruf yang digunakan pada media cetak harus mudah dibaca dan memiliki tata letak yang sesuai (Monica, 2010). Informasi yang disampaikan di dalam booklet juga dibuat dengan jelas dan tidak mengandung kata yang ambigu, supaya nantinya peserta didik tidak bingung dalam memahami materi tersebut. Aspek kebahasaan berkaitan dengan penggunaan kalimat yang jelas agar tidak menimbulkan kebingungan bagi siswa (Martha, 2018).

Dilihat dari aspek penyajian, booklet yang dikembangkan termasuk kriteria yang sangat valid. Hal ini menunjukkan pada penyajian booklet telah disusun secara sitematis. Sumber belajar yang disusun secara sistematis akan membuat peserta didik menjadi mudah dalam belajar dan senang mengikuti pembelajaran. lustrasi dan gambar yang disajikan pada booklet juga relevan dengan materi bakteri. Tampilan booklet yang dikembangkan juga telah dibuat semenarik mungkin dengan pemberian gambar dan ilustrasi dan pemberian warna pada setiap halaman, sehingga nantinya peserta didik semakin termotivasi untuk belajar. Media yang menarik akan mampu mebuat suasana pembelajaran berbeda, hal ini akan berdampak terhadap peningkatan keaktifan siswa dalam proses pembelajaran (Dewi et al., 2020), serta meningkatkan motivasi siswa dalam proses pembelajaran (Panjaitan, 2017; Sukiyasa \& Sukoco, 2013). Media juga membawa pengaruh terhadap psikologis (batin, perasaan, sikap, dan karakter) siswa (Yusantika et al., 2018). Berdasarkan aspek kegrafikan booklet memiliki kriteria yang sangat valid. Hal tersebut menunjukkan bahwa booklet yang memuat jenis huruf yang menarik sehingga diharapkan nantinya dapat meningkatkan semangat peserta didik ketika belajar. Booklet juga memiliki ukuran huruf yang serasi pada setiap katanya, sehingga tampilannya akan terlihat lebih rapi. Salah satu yang menjadi faktor penghambat pada tingkat keterbacaan yaitu penyusunan paragraf yang kurang teratur baik penulisan maupun urutan idenya.

Hal ini menunjukkan bahwa booklet telah dikembangkan telah valid dari berbagai aspek berdasarkan penilaian dari validator. Berdasarkan hasil angket tersebut booklet yang dikembangkan dapat digunakan oleh peserta didik sebagai sumber belajar pada saat pembelajaran. hasil penelitian ini memperkuat hasil penelitian yang menyatakan media booklet dengan huruf braille efektif dalam meningkatkan pengetahuan gizi pada anak tunanetra (Ulya et al., 2014), media booklet valid digunakan sebagai media informasi (Ajizatunnisa et al., 2018). Media booklet valid, pratis dan efesien diterapakan dalam proses pembelajaran (Ningrum \& Jayusman, 2017). Jadi dapat dikatakan bahwa media booklet mampu membuat suanasan pembelajaran lebih menarik.

\section{Simpulan}

Media booklet pada materi bakteri untuk peserta didik kelas X SMA yang dihasilkan sangat valid dengan katagori sangat baik. Sehingga booklet yang dikembangkan tersebut layak digunakan sebagai sumber belajar oleh peserta didik dalam proses belajar mengajar.

\section{Daftar Rujukan}

Ajizatunnisa, A., Wahyuni, S., Waluyo, L., \& Miharja, F. J. (2018). Booklet development based on research identification of fiddler crab (Uca spp.) diversity in mangrove ecosystem. Jurnal Pendidikan Biologi Indonesia, 4(1), 61. https://doi.org/10.22219/jpbi.v4i1.5337. 
Astuti, I. A. D., Dasmo, D., \& Sumarni, R. A. (2018). Pengembangan Media Pembelajaran Berbasis Android Dengan Menggunakan Aplikasi Appypie Di Smk Bina Mandiri Depok. Jurnal Pengabdian Kepada Masyarakat, 24(2), 695. https://doi.org/10.24114/jpkm.v24i2.10525.

Dewi, T. M., Mirnawati, \& Dirneti. (2020). Pengaruh Penggunaan Media Kartu Kata Bergambar dan Metode Konvesional Terhadap Hasil Belajar Kemampuan Membaca Siswa pada Kelas II di SDS 016 Muhammadiyah Karimun Tahun Ajaran 2019/2020. Jurnal Pendidikan MINDA, 1(2). https://ejurnal.universitaskarimun.ac.id/index.php/mindafkip/article/view/120.

Fitriasih, R., Kasrina, I., \& Kasrina, K. (2019). Pengembangan Booklet Keanekaragaman Pteridophyta Di Kawasan Suban Air Panas Untuk Siswa Sma. Diklabio: Jurnal Pendidikan Dan Pembelajaran Biologi, 3(1), 100-108. https://doi.org/10.33369/diklabio.3.1.100-108.

Hanzen, W. F. E., Hastuti, U. S., \& Lukiati, B. (2016). Pengembangan booklet pembuatan yoghurt kulit buah naga untuk para petani buah berbasis pada hasil penelitia. Jurnal Pendidikan, 1(11), 2140-2144. http://journal.um.ac.id/index.php/jptpp/article/view/7976/3625.

Hwang, G. J., Wang, S. Y., \& Lai, C. L. (2020). Effects of a social regulation-based online learning framework on students' learning achievements and behaviors in mathematics. Computers and Education, 160, 104031. https://doi.org/10.1016/j.compedu.2020.104031.

Intika, T. (2018). Pengembangan Media Booklet Science for Kids Sebagai Sumber Belajar Di Sekolah Dasar. JRPD (Jurnal Riset Pendidikan Dasar), 1(1), 10-17. https://doi.org/10.26618/jrpd.v1i1.1234.

Kkese, E. (2020). McGurk effect and audiovisual speech perception in students with learning disabilities exposed to online teaching during the COVID-19 pandemic. Medical Hypotheses, 144(July), 110233. https://doi.org/10.1016/j.mehy.2020.110233.

Kristiono, N., \& Mutmainah. (2018). Pemanfaatan Media Wayang Kertas untuk Meningkatkan Mutu Perkembangan Karakter Bahasa Anak dalam Berkomunikasi Verbal. Jurnal Penjaminan Mutu, 4(2). https://ejournal.ihdn.ac.id/index.php/JPM/article/download/569/481.

Lage-Cala, S., Folgueras-Díaza, M. B., Alonso-Hidalgoa, M., García-Menéndezb, D., \& Fernández-Garcíab, F. J. (2020). Investigation of the effectiveness of online learning tools for energy performance certificates preparation. Energy Reports, 6, 609-614. https://doi.org/10.1016/j.egyr.2019.09.034.

Lestari, A. I., Senjaya, A. J., \& Ismunandar, D. (2019). Pengembangan Media Pembelajaran Berbasis Android Menggunakan Appy Pie Untuk Melatih Pemahaman Konsep Turunan Fungsi Aljabar. Pedagogy: Jurnal Pendidikan Matematika, 4(2), 1-9. https://doi.org/10.30605/pedagogy.v4i2.1437.

Martha, I. N. (2018). Pemilihan Materi/Aspek Kebahasaan Dalam Kurikulum 2013 Pada Jenjang Pendidikan Menengah (Smp/Msn, Sma/Ma, Smk). Prasi, $13(2), \quad 42$. https://doi.org/10.23887/prasi.v13i2.16451.

Monica. (2010). Pengaruh warna, tipografi, dan layout. Komunikasi Multimedia, 9, 459-468.

Ningrum, A. F., \& Jayusman, S. A. (2017). Pengembangan Bahan Ajar Sejarah Berbentuk Booklet Pada Materi Proklamasi Kemerdekaan Indonesia dalam Upaya Peningkatan Minat Belajar Siswa Kelas XI SMAN 1 Kertek Wonosobo Tahun Pelajaran 2016/2017. Indonesian Journal of History Education, 5(1), 1-8. https://journal.unnes.ac.id/sju/index.php/ijhe/article/view/19914.

Nomleni, F. T., \& Manu, T. S. N. (2018). Pengembangan Media Audio Visual dan Alat Peraga dalam Meningkatkan Pemahaman Konsep dan Pemecahan Masalah. Scholaria: Jurnal Pendidikan Dan Kebudayaan, 8(3), 219-230. https://doi.org/10.24246/j.js.2018.v8.i3.p219-230.

Panjaitan, S. (2017). Meningkatkan Hasil Belajar Ipa Melalui Media Gambar Pada Siswa Kelas Iia Sdn 78 Pekanbaru. Primary: Jurnal Pendidikan Guru Sekolah Dasar, 6(1), 252. https://doi.org/10.33578/jpfkip.v6i1.4105.

Paramita, R., Panjaitan, R. G. P., \& Ariyati, E. (2019). Pengembangan Booklet Hasil Inventarisasi Tumbuhan Obat Sebagai Media Pembelajaran Pada Materi Manfaat Keanekaragaman Hayati. Jurnal IPA \& Pembelajaran IPA, 2(2), 83-88. https://doi.org/10.24815/jipi.v2i2.12389.

Pralisaputri, K. R., Soegiyanto, H., \& Muryani, C. (2016). Pengembangan Media Booklet Berbasis SETS Pada Materi Pokok Mitigasi Dan Adaptasi Bencana Alam Untuk Kelas X Sma. Jurnal GeoEco, 2(2), 147154.

Puspita, A., Kurniawan, A. D., \& Rahayu, H. M. (2017). Pengembangan Media Pembelajaran Booklet Pada Materi Sistem Imun Terhadap Hasil Belajar Siswa Kelas Xi Sman 8 Pontianak. Jurnal Bioeducation, 4(1), 64-73. https://doi.org/10.29406/524.

Rehusisma, L. A., Indriwati, S. E., \& Suarsini, E. (2017). Pengembangan Media Pembelajaran Booklet Dan Video Sebagai Penguatan Karakter Hidup Bersih Dan Sehat. Jurnal Pendidikan: Teori, Penelitian, Dan Pengembangan, 2(9), 1238-1243. http://journal.um.ac.id/index.php/jptpp/article/view/9964/4705.

Situmorang, R. P., \& Andayani, E. P. (2019). Penggunaan Media Animasi Berbasis Macromedia Flash untuk Meningkatkan Hasil Belajar Siswa pada Konsep Materi Sistem Peredaran Darah Manusia. 
Assimilation: Indonesian Journal of Biology Education, 2(1), 35. https://doi.org/10.17509/aijbe.v2i1.14544.

Sukiyasa, K., \& Sukoco, S. (2013). Pengaruh media animasi terhadap hasil belajar dan motivasi belajar siswa materi sistem kelistrikan otomotif. Jurnal Pendidikan Vokasi, 3(1), 126-137. https://doi.org/10.21831/jpv.v3i1.1588.

Ulya, E., Budiono, I., \& Mardiana. (2014). Efektivitas Media Booklet Braille Dalam Meningkatkan Pengetahuan Gizi Pada Anak Tunanetra. Unnes Journal of Public Health., 3(4), 48-55. https://doi.org/10.15294/ujph.v3i4.3888.

Wijayanti, E., Rohman, F., \& Hastuti, U. S. (2016). Pengembangan Booklet Penyuluhan “ Nata De Pamelo" Bagi Para Petani Jeruk Pamelo Di Magetan. Jurnal Pendidikan, 1(5), 874-880.

Yusantika, F. D., Suyitno, I., \& Furaidah. (2018). Pengaruh Media Audio dan Audio Visual terhadap Kemampuan Menyimak Siswa Kelas IV. Jurnal Pendidikan, 3(2), 251-258. https://doi.org/http://dx.doi.org/10.17977/jptpp.v3i2.10544.

Yusuf, M., Saraswati, U., \& Ahmad, T. A. (2019). Pengembangan Bahan Ajar Perang Lasem Dalam Bentuk Booklet Untuk Pembelajaran Sejarah Lokal Di Sma Negeri 1 Lasem. Indonesian Journal of History Education, 7(1), 50-58. https://doi.org/10.15294/ijhe.v7i1.32287. 